These are presented by responsible workers from this country and from abroad.

It is a pleasure to record that the photographs are excellent and few have lost anything of their original quality. The photo-micrographs not only show what is claimed but they are technically as good as anything available anywhere for teaching purposes. Since the war it is rare for a British production to be better in this respect than its American rivals.

This book can be read with advantage by anyone who feels that his knowledge of this group of diseases is inadequate or may be out of date. It will give him a clear picture of the present state of knowledge and honestly draw attention to the gaps yet to be filled.

W.H.H.

\section{ABDOMINAL OPERATIONS BY THE VAGINAL ROUTE}

By Paul M. Werner, M.D. and Julius Sederl, M.B. (Translated from the German by L. M. Szamec, M.D.) Pp. vi + I65, fully illustrated. London: Pitman Medical Publishing Co. Ltd. 1958. $65 \mathrm{~s}$.

This is an American translation of a book by two Viennese gynaecologists. It describes vaginal hysterectomy, including the removal of the large fibroid uterus by morcellation, vaginal removal of ovarian tumours, the vaginal route for dealing with ectopic pregnancy, tubal sterilization by the vaginal route and the interposition operation.

On the continent of Europe, especially in Austria and Italy and in certain States of America such as California, vaginal gynaecological surgery has reached an extremely high standard: probably unequalled any where in this country. This book is worth consulting as an object lesson how to carry out vaginal procedures in those few patients in this country who refuse to have an abdominal scar.

Even the authors of this book, enthusiastic as they are, do not recommend the vaginal route for ectopic pregnancy but they do show how such a condition can be dealt with vaginally.

The most remarkable pages in the book, as far as your reviewer is concerned, are those showing the method perfected by Logothetopulos.

Any bleeding in the pelvis can for certain be stopped by the insertion of a massive tampon. The method is ingenious in the extreme and probably effective too. Because of it, the nightmare of the lipped pedicle in vaginal surgery has disappeared. (Your reviewer tried it out on a case of a combined synchronous abdominoperineal anterior extenterafion in a very old lady and found it roo per cent. effective.)

This is a book that every gynaecological surgeon ractising really major surgery should own or at least ead. It is not a book for undergraduates, nor eally for the post-graduate student.

It is very well produced.

\section{TOPICJ IN PSY CHIATRY}

Edited by T. Ferguson Rodger, R. M. MowBRAY and J. R. Roy. Pp. $x+265$. London: Cassell \& Co. Ltd. I 958 . 20s.

In this volume some two dozen contributors record the Proceedings of a Specialist Conference in Psychiatry held in Glasgow in October 1957. The added impetus which psychiatric research has received in the last year or two makes this a singularly opportune time to record facets of progress in this specialty by a well-organized and enthusiastic group of clinical scientists.

There are five sections, each with its own editorial introduction, covering schizophrenia, psychosomatic medicine, tranquillizing drugs, mental deficiency, and biochemical genetics. The papers which make up these sections do not pretend to be comprehensive or exhaustive, but each in its modest way makes a definite contribution to the subject as a whole, and possesses an inter-relevance wisely pointed out in the editorial.

The chapters vary considerably in length and quality, but the careful editing prevents this from appearing as an uneven text. Completely free from theoretical bias and with no adherence to any one school of thought, this book provides a very good vignette of mid-century psychiatry, in which psychoanalysis rubs shoulders with psychopharmacology, and explanations range from the verballyo descriptive to the analytically statistic.

As well as pointing out the dominant problemse facing psychiatry today, this book carries an optimism shared by most of its contributors for the future of that backwater of medicine-mental deficiency. It is very satisfying to see so much interest in oligophrenia not only maintained but directed in a positive manner towards solutions of what are often thought to be insoluble problems.

This is an inexpensive volume which gives an informative and very readable account of contemporary psychiatric research, pointing out most clearly, not only the changing face of psychiatry, but the way in which so many disparate viewpoints can profitably converge.

\section{MUIR'S TEXTBOOK OF PATHOLOGY}

Revised by D. F. CAppell, C.B.E., M.D., F.R.F.P.S., M.R.C.P., F.R.S.(Edin.). Seventh Edition. Pp. $x x+1201$, with 733 illustrations. London: Edward Arnold Ltd. 1958.70 .

The ever-increasing volume of medical knowledge makes the production of a single-author textbook seemingly impossible, yet Professor Cappell, in this seventh edition of 'Muir,' has succeeded in writing a really up-to-date account of pathology.

A particularly pleasing feature is the way in which the functional aspects of disease are discussed as well as the morphological, for it was this slavish devotion to purely morbid anatomical 
description which did so much to stultify the student's interest in pathology in the past.

The only real criticism of this splendid book is the omission of references to original articles, the reading of which might stimulate the better type of student to give more thought to the subject. There is, however, a long list of the more important monographs and books of reference, which to some degree compensates for this omission.

The illustrations are plentiful and of good quality, and the indexing is excellent.

This new edition, even more than its forerunners, can be confidently recommended to both undergraduates and those at a more advanced stage of their careers.

\section{NEUROLOGICAL BASIS OF BEHAVIOUR}

\section{Ciba Foundation Symposium}

Edited by G. E.' W. Wolstenholme, O.B.E., M.B., Ch.B. and Cecilia M. O'Connor, B.Sc. Pp. xi +400 , illustrated. London: J. \& A. Churchill Ltd. I $958.52 \mathrm{~s} .6 \mathrm{~d}$.

This book is the printed record of the proceedings of a symposium held in commemoration of Sir Charles Sherrington in the year 1957 . It contains I 9 papers on the physiology and biochemistry of human reactions, and notes on the discussions after each paper.

For the clinician, much of the material in the book will seem recondite. The report of the behaviour of the chronically decebrate cat belongs to the province of zoology, and seems to have little bearing on the understanding of disorders $\bar{\delta}$ the human organism. Wilder Penfield's paper \&n the role of the temporal cortex, on the other hand, will set off a number of trains of thought in reader who is interested in the mechanisms of memory in man. Experimental work describd elsewhere in the text, diligent and scrupulows though it is, will serve to remind us how little really know about what goes on in the brain; limitations of a r'aysical approach to the phenomema of mind are here clearly shown.

\section{THE FACTS OF MENTAL HEALTH AND ILLNESS}

By K. R. Stallworthy, M.B., Ch.B., D.P.X. Second Edition. Pp. 218. Christchurch, New Zealand: N. M. Peryer Ltd. I958. 22s. 6d $\overrightarrow{\mathrm{E}}$

Two year; have elapsed since I reviewed the first edition of this popular account of psychologiol medicine. There has not been a great deal of alteration in this new edition, which is praise enough for the basic quality of the work, and before, the book remains one of the best intro ductions to the subject for lay and medical reages alike. One acceptable innovation is the provion of a cloth binding in place of the paper coves of the earlier edition, giving permanence to $5+e^{2}$ volume and an improved appearance which mo than justifies the small increase in price.

\section{Manufacturers' Notes}

\section{HUNSLET RADIO-COBALT THERAPY EQUIPMENT}

One of the more important steps forward in the peaceful uses of atomic energy was taken with the production, by nuclear reaction, of Radioactive Cobalt. 'The advantages of the use of this source of high energy radiation in comparison with existing deep therapy are well known:

Radiation equivalent in penetrating power to that emitted by an X-ray tube operated at approximately 3 million volts.

Greater depth dose.

Lower selective absorption in bone.

Decreased skin dose.
When this new and intense source of radiati局 was first made available for treatment and research. the Hunslet Precision Engineering Ltd., with in extensive resources in heavy precision engineers ing, was privileged to co-operate with the radid therapy department of a Leeds teaching hospitat in the design and construction of the necessary equipment.

Since then, there has been perfected at Hunslet a comprehensive range of Radio Cobalt Units designed to serve the needs of moving and stationary field therapy and research with ease of control, speed and precision of operation com: bined with absolute safety under all conditions. 